\title{
A comparative study of the components of the hard coral Seriatopora hystrix and the soft coral Xenia umbellata along the Jeddah coast, Saudi Arabia
}

\author{
Estudio comparado de los componentes del coral duro Seriatopora hystrix y del coral blando Xenia \\ umbellata en la costa de Jeddah, Arabia Saudita
}

\author{
A. A. Al-Sofyani ${ }^{1}$ and G. R. Niaz ${ }^{2}$ \\ ${ }^{1}$ Marine Biology Department, Marine Science Faculty, King Abdulaziz University. P.O. Box 53190, Jeddah-21583, Saudi Arabia \\ ${ }^{2}$ Marine Chemistry Department, Marine Science Faculty, King Abdulaziz University. P.O. Box 53190, Jeddah-21583, Saudi Arabia \\ Sofyani@hotmail.com
}

Resumen.- En este estudio se compararon la estructura de los pólipos y los tipos celulares del coral duro Seriatopora hystrix y del coral blando Xenia umbellata, además de la composición de los ácidos grasos en sus tejidos. S. hystrix mostró una aparente carencia de células alimenticias especializadas, particularmente, un pequeño número de células glandulares mucosas y un bajo porcentaje de nematocistos conteniendo veneno. Los P-mastigóforos estuvieron presentes en el 1,52-5,7\% de los nematocistos y los B-mastigóforos en el 1,28\%. Por el contrario, hubo un alto porcentaje de nematocistos holotricos (24,86 - 55,5\%) en los tentáculos y filamentos mesentéricos, respectivamente. Las zooxantelas fueron abundantes en la gastrodermis. Estas características sugieren que $S$. hystrix depende esencialmente de una nutrición autótrofa. Los pólipos de $X$. umbellata no presentaron cnidae, $\mathrm{y}$ las glándulas mucosas fueron abundantes, especialmente en la parte más basal del pólipo. La presencia de materia particulada en el celenteron y el bajo número de zooxantelas indican que $X$. umbellata es un suspensívoro, que utiliza mucus para atrapar las partículas en los tentáculos pinados.

Un estudio comparativo de su composición química también reveló diferencias entre ambas especies. $X$. umbellata presentó un alto contenido proteico y lipídico mientras que $S$. hystrix se caracterizó por un alto contenido de carbonato de calcio. En $S$. hystrix, los ácidos grasos fueron predominantemente saturados (87,3\%), siendo 16:0 y 18:0 los más abundantes. $X$. umbellata mostró predominancia de ácidos grasos insaturados (77,7\%), siendo 16:1 y 18:1 los más abundantes. Las diferencias morfológicas y en composición bioquímica sugieren que $S$. hystrix tiene mayor dependencia de una alimentación autótrofa mientras que $X$. umbellata es mas bien un suspensívoro heterótrofo.

Palabras clave: Tipo cnidae, competencia, arrecifes de coral, estrategias de alimentación, Mar Rojo

\begin{abstract}
In this study, the structure of the polyps and the cell types of the hard coral Seriatopora hystrix and the soft coral Xenia umbellata were compared, together with the composition of the fatty acids in their tissues. S. hystrix displayed an apparent lack of specialized feeding cells, notably the relatively small number of mucous gland cells and the low percentage of venom containing nematocysts. P-mastigophores accounted for $1.52-5.7 \%$ and, Bmastigophores for $1.28 \%$ of the nematocysts. Conversely there was a high percentage of holotrichs nematocysts (24.86 - 55.5\%) in the tentacles and mesenterial filaments respectively. Zooxanthellae were abundant in the gastrodermis. These charateristics suggest that $S$. hystrix relies essentially upon autotrophic nutrition. The polyps of $X$. umbellata were devoid of cnidae, and mucous glands were in abundance, particularly in the lower part of the polyp. The presence of particulate matter in the coelenteron, and low number of zooxanthellae indicate that $X$. umbellata is a suspension feeder, using mucus to trap the particles on the pinnate tentacles.

Differences were also revealed by a comparative study of their chemical composition. X. umbellata had a high protein and lipid content, whilst $S$. hystrix was characterized by high calcium carbonate content. In $S$. hystrix, the fatty acids were found to be predominantly saturated fatty acids (87.3\%), the most abundant being 16:0 and 18:0. X. umbellata showed a predominance of unsaturated fatty acids (77.7\%), the most abundant being 16:1 and 18:1. The differences in morphology and in biochemical composition suggest that $S$. hystrix has a greater reliance on autotrophic feeding whilst $X$. umbellata is a more heterotrophic suspension feeder.
\end{abstract}

Key words: Cnidae type, competition, coral reefs, feeding strategies, Red Sea 


\section{Introduction}

Corals are ubiquitous in the marine organization. The Red Sea contains about 47 genera of different corals that include about 250 different species of various types of coral (Ditlev 1980). Most of these are stony corals with a few soft corals. They have different types of corallites and therefore exhibit different physiological adaptation to their marine environment. The type of nutritional regime can be studied by chemical and biological examination. The present study was designed to analyze comparatively the chemical and the biological aspects and to study the mode of nutrition in two coral species.

Differences in feeding strategy between two different types of corals, the stony coral Seriatopora hystrix Dana, 1846 and the soft coral Xenia umbellata Savigny, 1816 were investigated. S. hystrix is a widespread species occuring in a variety of habitats from shallow sublittoral down to around $30 \mathrm{~m}$ depth. It is most abundant in sheltered lagoon areas where it develops large colonies. In such areas it commonly coexists and competes with $X$. umbellata.

Until now, no comparative studies on the histology and biochemistry of coral polyps have been made in order to relate cell type, size and chemical constitution to different modes of feeding. Most of our knowledge on the feeding behaviour of the polyps has come from observations on ciliary activity and from the morphology of the coral polyp's reef. Corals with a small polyp diameter should be predominantly phototrophic while those species with large polyp or a massive form should show a greater degree of heterotrophism (Wellington 1982). The mucous-gland cells, which secrete the mucus for suspension feeding, occur mainly in the epidermal layer. However, it has been shown that whilst the mucus is used in protection and cleansing, its main use is in food capture (Goldberg 2002).

The epidermal cnidae serve a variety of functions: prey capture, adhesion, defense and aggression (Thorington \& Hessinger 1990). The two major groups of cnidae involved in feeding are spirocysts, which capture zooplankton by attaching to the surface of the prey, and nematocysts, which are used to capture prey by injection of a toxic substance (Mariscal 1974). Corals can also obtain nutritional benefit from their zooxanthellae. It was observed that corals with symbiotic algae had an increased lipid/protein ratio, indicating the translocation of photosynthetic product into the host tissue (Szmant-Froelich \& Pilson 1980). In addition to this observation it was observed that corals feeding on some prey had greater biomass i.e. it was observed that when two species of coral Stylophora pistillata were grown under different conditions, one group was fed with Artemia sp. and the second group was kept under starvation. Fed corals exhibited greater biomass compared to starved corals (Reynaud et al. 2002).

Zooxanthellae can procure their food via photosynthesis and can pass it on to the animal. When the hard coral Pocillopora damicornis was kept in darkness, the tissue biomass was significantly lower than when kept in sunlight, indicating that it was dependant upon energy derived from photosynthesis by zooxanthellae (Clayton \& Lasker 1982). Subsequently, it was confirmed that the zooxanthellae are the major sites of lipid synthesis in the light (Kellogg \& Patton 1983). It now appears likely that during photosynthesis, labeled carbon is incorporated into lipid, mainly as triglyceride and glycerol. The glycerol is thought to be used as a substrate for respiration by the host cells (Davy \& Cook 2001). The nature of the lipid in coral tissues is related to the mode of nutrition. Corals with predominant unsaturated fatty acids relied more on plankton capture, while corals with abundant saturated fatty acids relied more on the photosynthetic products translocated from their zooxanthellae (Meyers 1979). Oku (2003) observed in coral Montipora digitata the low molecular weight compounds; sugars and amino acids once translocated from zooxanthellae to host cell were metabolized towards lipogensis as well as glycerol production. It was studied by a Russian group of workers (Papina et al. 2003) that when zooxanthellae were separated from the host animal and their fatty acids were determined separately by GC-MS, it was revealed that the zooxanthellae had a higher percentage of unsaturated fatty acids, so in short it is a point of controversy among the scientists that it is not always necessary that symbiotic algae would always reveal the formation of saturated fatty acids. A comparative light-dark feeding study of the coral Galaxea fascicularis showed that in dark the metabolic requirement of the zooxanthellae were in part met from the animal host through a heterotrophic mode of nutrition (Al-Moghrabi 1995), so it is difficult to anticipate that the unsaturated compounds would be predominantly from the host cell, an element of uncertainty is observed. 
This study was undertaken therefore to determine whether $S$. hystrix and $X$. umbellata displayed morphological and biochemical composition differences that may reflect differences in their feeding strategy.

\section{Material and methods}

Samples were collected from Ubhur Creek (Fig.1) during December 2005, from a depth of $3 \mathrm{~m}$. This creek lies at the north of Jeddah; it is $11 \mathrm{~km}$ long, its maximum width is $350 \mathrm{~m}$ and the maximum depth is 35 $\mathrm{m}$ (approximately in the middle of the creek). The salinity ranges from 39 to 42 psu during most part of the year. Samples for histological examination were relaxed for six hours in solution of $3.5 \% \mathrm{MgSO}_{4}$ and then preserved in $7 \%$ sea water/formalin for at least three days. Thereafter, specimens of stony coral were transferred to a $7 \%$ solution of nitric acid to decalcify the skeletons. The decalcified hard coral polyps and soft corals were washed with distilled water and preserved in $70 \%$ ethanol for histological study. Parts of the specimens that were to be examined for lipid were post-fixed in potassium dichromate-osmium tetroxide solution ( $50 \mathrm{ml} 2 \%$ osmium tetroxide and 50 $\mathrm{ml} 5 \%$ potassium dichromate) for eight hours. Thereafter, the post-fixed samples were washed in running water for two hours and preserved in $70 \%$ ethanol.

The preserved specimens were dehydrated in a series of strengths of ethanol, and then cleared in xylene. The cleared specimens were infiltrated and embedded in paraffin wax. Serial sections, $7 \mu \mathrm{m}$ in thickness, were cut and then stained with Haematoxylin and Eosin. Another series of sections were stained with Alcian Blue and Neutral Red, to differentiate the mucous-glands. The stained sections were cleared with xylene and mounted in Canada balsam.

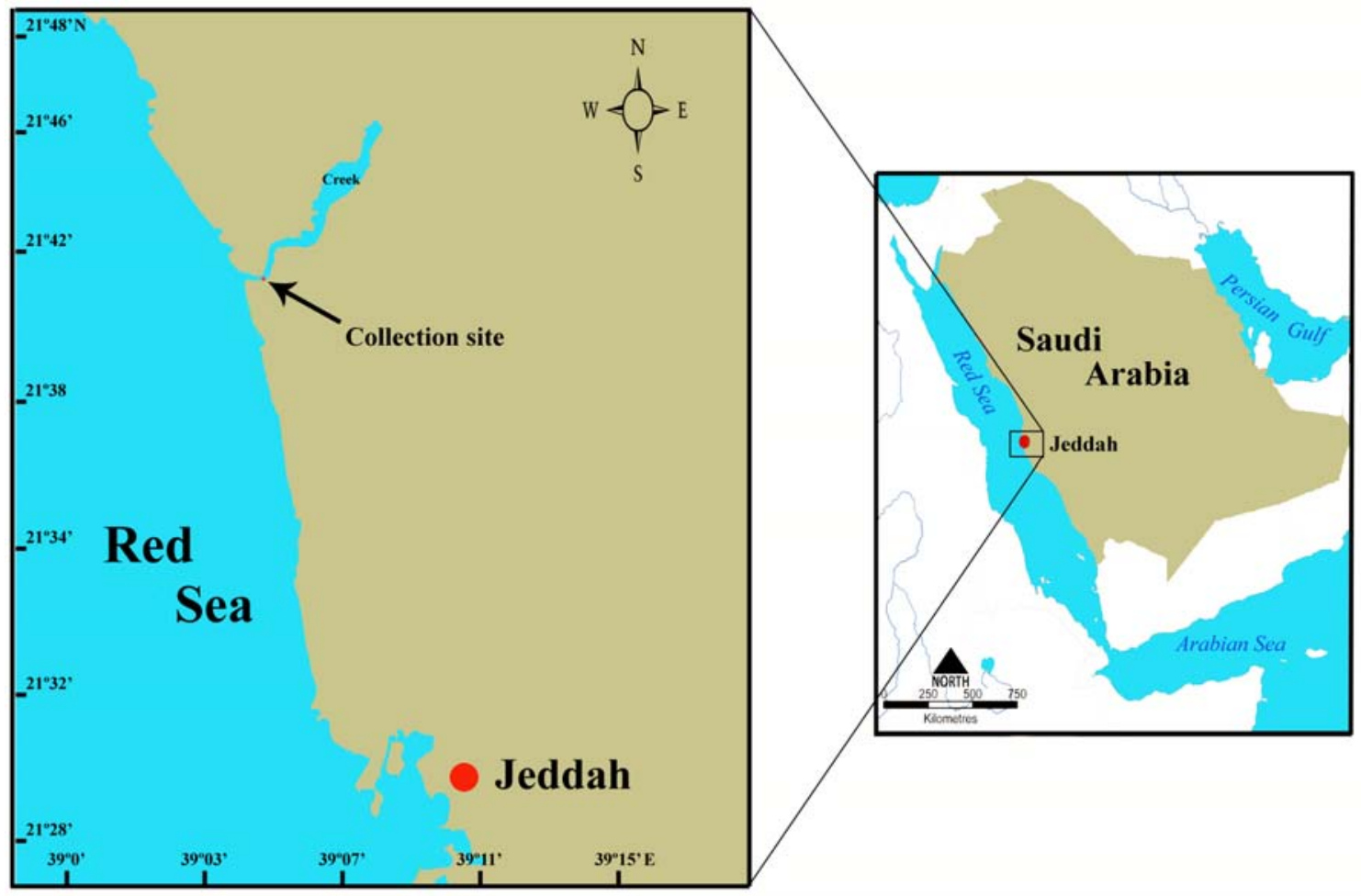

Figure 1

Map of the Red Sea showing the location of the study site at the entrance of Ubhur Creek

Mapa del Mar Rojo mostrando la ubicación del sitio de estudio a la entrada de Ubhur Creek 
Samples of tentacle tips, mesenterial filament and oral disc were dissected from the polyps and placed in a solution of $5 \%$ potassium hydroxide overnight at a temperature of $5^{\circ} \mathrm{C}$. Pieces of tissue were then mounted on a slide and squashed beneath a coverslip. The number, type and size of cnidae were recorded using a microscope with a times 1000 oil-immersion objective. The oral disc was divided into four pieces before counting, and the mesenterial filaments divided into two pieces. Estimates of the total population of cnidae were then made. Biomass measurements were determined according to the method of Davies (1991).

The unit reference was dry skeletal weight which was calculated from the buoyant. The technique involves the weight of the living branches (nubbins) of $S$. hystrix in sea water and converting the buoyant weight to the dry weight of skeleton by the following equation of Davies (1989):

(i) Dry weight of the object $=$ weight in water $\div$ [1density of water / density of object]

(ii) Buoyant weight of object $=$ weight in air * [1density of water /density of object]

(iii) Density of water $=$ weight in air-weight in water $\div$ (weight in air/ density of object)

(iv) Density of object $=$ (weight in air $*$-density of water)/ (weight in air-weight in water)

The skeleton density of $S$. hystrix was obtained by removing the tissue from the skeleton. A group of ten nubbins from $S$. hystrix was left in $10 \%$ solution of chlorox and seawater for two days. The skeleton was then cleaned with a water jet to remove any residual tissue. Their buoyant weights were recorded in seawater and its density was measured immediately before buoyant weighing the skeleton. Thereafter, the skeletons were rinsed in distilled water and dried to a constant weight at $60^{\circ} \mathrm{C}$. The skeleton density was then calculated from the equation of Davies (1989).

Skeletal weight and dry tissue weight were obtained by a group of 10 nubbins which were buoyant weighed and then fixed in $7 \%$ formalin, decalcified in $10 \%$ nitric acid and then dried the resultant tissue to constant weight at $60^{\circ} \mathrm{C}$. The dry tissue weight was related to dry skeletal weight and expressed as mg dry tissue wt/g skeletal wt. Skeletal weight and number of zooxanthellae were calculated by fixing the nubbins in formalin, decalcifying in $10 \%$ nitric acid and then homogenizing the distilled water-washed resultant tissue with a hand-held potter homogenizer, after which the suspension was centrifuged and distilled waterwashed three times. They were resuspended in $1 \mathrm{~mL}$ of filtered distilled water and zooxanthellae concentrations within the cell were measured on a sub sample using a haemacytometer. The relationship between the zooxanthellae number and the dry tissue weight was estimated indirectly. Aluminum foil was fitted carefully on to the surface of each nubbin. The fitted foil was then weighed and a value for surface area derived, in order to obtain a relationship between surface area and skeletal weight. The number of polyps per $\mathrm{cm}^{2}$ was obtained from the number of calices per $\mathrm{cm}^{2}$.

For chemical analysis, the top $2 \mathrm{~cm}$ of the branch of S. hystrix was used. The skeleton was examined under a stereo microscope, and found to be free from endolithic algae and gall-forming crabs. Water content was determined by drying the coral at $70^{\circ} \mathrm{C}$ for $48 \mathrm{~h}$ till constant weight. Residual matter was estimated by heating in a muffle furnace at $650^{\circ} \mathrm{C}$ for $48 \mathrm{~h}$ till constant weight. These corals were collected at a depth of $3 \mathrm{~m}$. Light is probably the most important factor after temperature as it effects the symbiosis between hermatic coral and zooxanthellae which live within the gastrodermal tissues of the coral and are apparently essential for the calcification, because the light intensity decreases exponentially with increasing depth; active coral reef building greatly diminishes below a depth of $25 \mathrm{~m}$ (Levinton 1982). Chlorophyll was determined by dissolving it in $90 \%$ aqueous acetone and measuring the absorbance at $665 \mathrm{~nm}$ and $645 \mathrm{~nm}$ for 'a' and 'b' type chlorophyll, respectively (Lichtenthaler et al. 1987).

Lipids were extracted using a modified Folch method (Folch et al. 1957). In the case of S. hystrix, additional amounts of lipids were obtained by decalcifying the residual matter with $10 \%$ formic acid (Harland et al. 1993). Methyl esters were prepared by hydrolyzing the lipid with $1 \mathrm{~mL}$ ethanol/potassium hydroxide solution under reflux for one hour. It was extracted with ether and partitioned with water. The aqueous layer neutralized with $5 \mathrm{~mL}$ hydrochloric acid and the free fatty acids extracted with chloroform. The free fatty acids were dissolved in tetrahydrofuran containing $5 \%$ methanolic hydrogen chloride solution. It was refluxed for $2 \mathrm{~h}$. Water containing $5 \%$ potassium chloride was added, the 
methyl esters were extracted with hexane. The hexane layer was washed with $2 \%$ potassium bicarbonate, dried over anhydrous sodium sulphate and the solvent evaporated in a stream of nitrogen. The fatty acid methyl esters were analyzed using gas chromatography (Shimadzu-17A) equipped with a fused silica capillary column (30 m* $0.25 \mathrm{~mm}$ i.d.) coated with ergs linked SP-2310. The oven temperature was programmed from 150 to $250^{\circ} \mathrm{C}$ at $50 \mathrm{~min}^{-1}$, the final temperature was maintained for $5 \mathrm{~min}$. The samples were further analyzed by gas-chromatography mass - spectrometry (GC-MS) on a Shimadzu QP-5000 quadrupole.

\section{Results}

\section{Morphology}

In Seriatopora hystrix, living colonies showed a variety of colours from light brown to brown-green. The polyps were extended during the day. Expanded polyps are $0.1 \mathrm{~mm}$ in diameter and up to $0.6 \mathrm{~mm}$ in length, with 12 short $(0.2 \mathrm{~mm})$ white tipped tentacles.

The epidermal layer comprised elongated columnar cells, nematocysts and a few mucous-gland cells (Fig. 2A, B). The mucous-gland cells were present in small

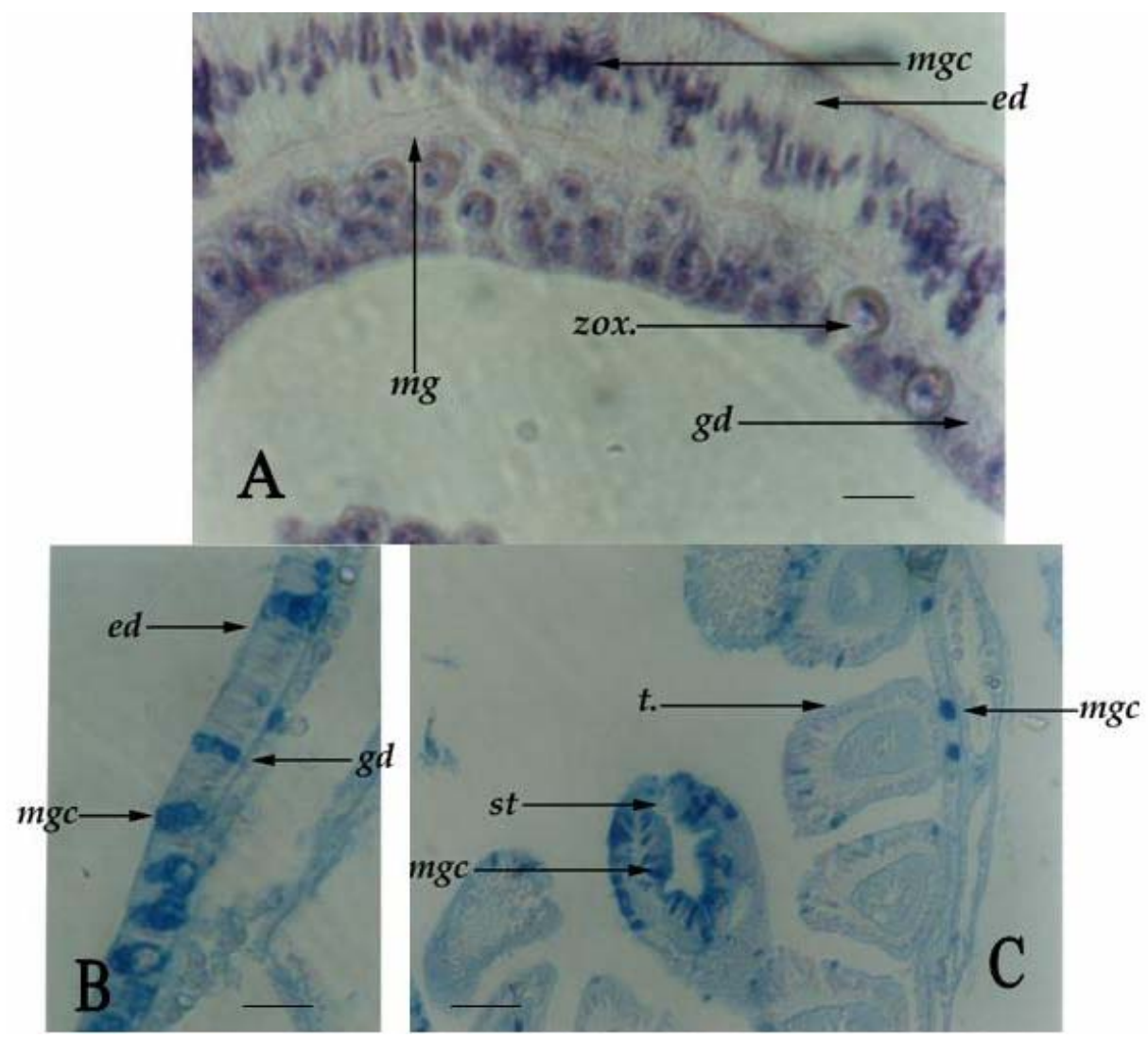

Figure 2

Histological sections through the polyp of $S$. hystrix. A. Cross-section through coenosarc, showing details of cell types occurring in each layer; ed, epidermis; gd, gastrodermis; mg, mesogloea; mgc, mucus-gland cell; zox, zooxanthellae. B. and C. Cross-section through the polyp. Note the shape and the color of mucus-gland cells when stained with Alcian Blue at pH 1. st, stomodaeum; t, tentacle

Cortes histológicos a través del pólipo de S. hystrix. A. Sección transversal a través de un coenosarco, mostrando detalles de los tipos celulares de cada capa; ed, epidermis; gd, gastrodermis; mg, mesoglea; mgc, célula glandular mucosa; zox, zooxantelas. B. y C. Corte transversal a través del pólipo. Note la forma y el color de las células glandulares mucosas al ser teñidas con azul alcian a pH 1. st, 
numbers in all tissues except the oral disc where they were present in large numbers. They are flask-shaped or elongated about $15.6 \mu \mathrm{m}$ in length (Fig. 2 B.C.). Lipid was stained black in osmium-tetroxide-fixed tissue. It was observed as black particles ranging from 6.0 to $19.5 \mu \mathrm{m}$ in diameter between the zooxanthellae, and in the gastrodermis of the lower half of the polyp (Fig. 4A.B.). Lipids were never observed in the epidermal layer.

Holotrichs and spirocysts were the predominant cnidae in the tentacles of S. hystrix (Fig. 3A). Their

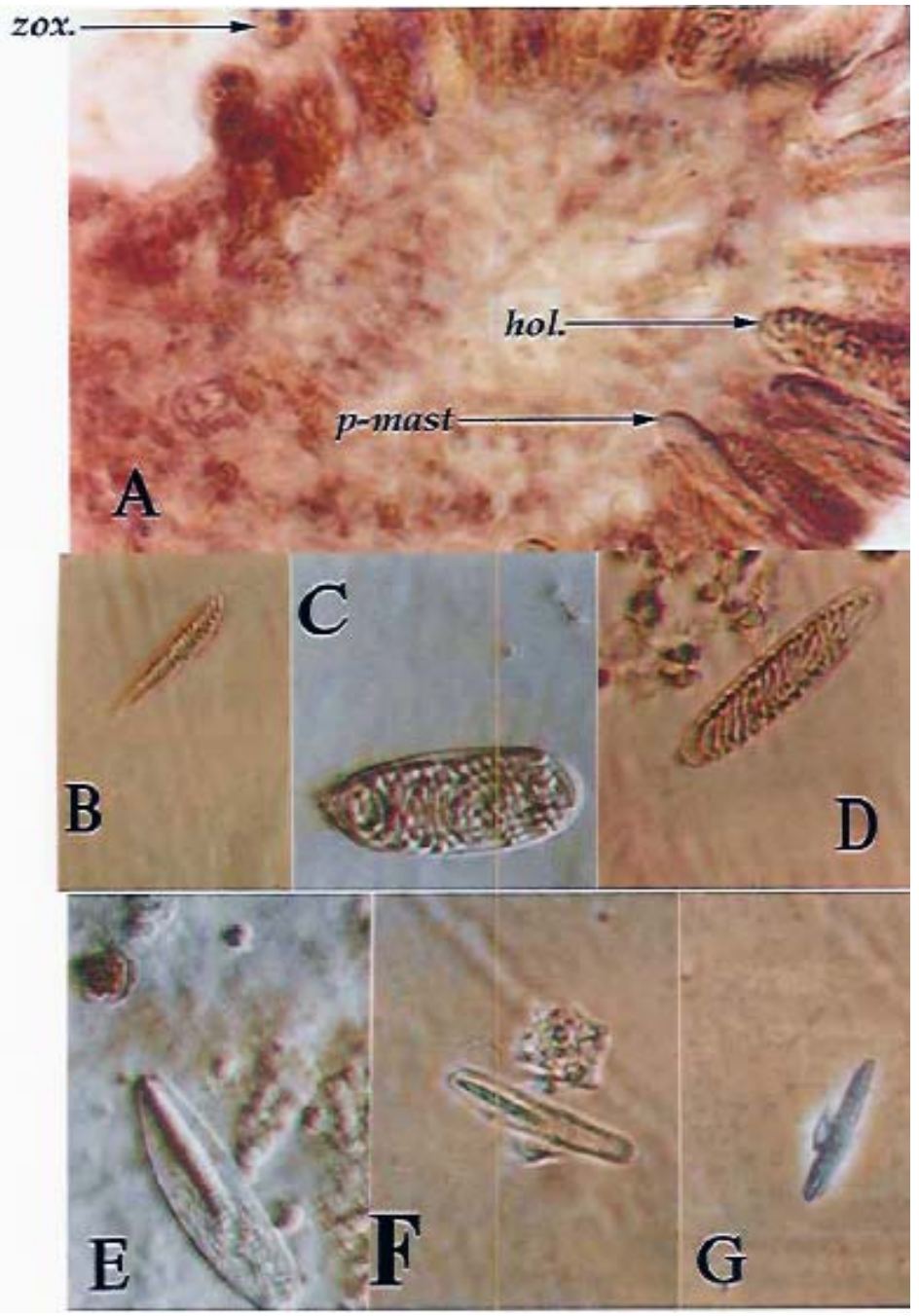

Figure 3

Longitudinal section through the tentacle of $S$. hystrix, showing cnidae types. A. hol., holotrich; p-mast, p-mastigophore. B-G. Types of cnidae found in. B, spirocysts; C, holotrich in tentacles; D, holotrich in stomodaeum; E, p-mastigophore in tentacle; F, p-mastigophore in stomodaeum and G, b-mastigophore in stomodaeum

Corte longitudinal a través del tentáculo de $S$. hystrix, mostrando los tipos de cnidae. A. hol., holotricho; p-mast, p-mastigóforo. B-

G. Tipos de cnidae encontrados. B, espirocistos; C, holotrichos en tentáculos; D, holotrichos en estomodeo; E, p-mastigóforo en tentáculo; F, p-mastigóforo en estomodeo y G, b-mastigóforo en estomodeo 
numbers were $1636 \pm 103$ and $736 \pm 54$ per polyp respectively (Table 1 ). The mean number of $\mathrm{P}$ mastigophore $(100 \pm 15)$ and B-mastigophore $(84 \pm 10)$ were relatively low. However, spirocysts were absent in the oral disc, and P-mastigophore, holotrichs and Bmastigophore were considerably lower in number.
Mesenterial filaments were devoid of spirocysts and Bmastigophores, while holotrichs were abundant (3620 \pm 775) and P-mastigophores were present but in lower number (378 \pm 34) (Fig. 3B-G). The distribution of the zooxanthellae was uniform throughout the polyp. Their average number was $1.57 * 10^{-5} \mathrm{mg}^{-1}$ dry tissue (Table 2 ).

Table 1

Average number, size and percentage distribution of cnidae type per polyp in each tissue type in $S$. hystrix (mean \pm standard deviation and sample size). Where size was uniform no standard deviation is given

Número promedio, talla y porcentaje de distribución de tipo de cnidae por pólipo en cada tipo de tejido en $S$. hystrix (media \pm desviación estándar y tamaño de muestra). Cuando la talla fue uniforme no se incluye la desviación estándar

\begin{tabular}{|c|c|c|c|c|}
\hline Cnidae type & & Tentacle & Oral disc & Filament \\
\hline \multirow[t]{4}{*}{ Spirocysts } & Mean & 736.00 & $*$ & $*$ \\
\hline & \pm s.d.(n) & $53.96(10)$ & $*$ & * \\
\hline & Size $\mu \mathrm{m}$ & 15.60 & $*$ & * \\
\hline & Percentage \% & 11.18 & $*$ & $*$ \\
\hline \multirow[t]{4}{*}{ P-mastigophores } & Mean & 100.0 & 18.0 & 378.0 \\
\hline & \pm s.d.(n) & $14.96(10)$ & $1.41(5)$ & $34.2(5)$ \\
\hline & Size $\mu \mathrm{m}$ & 27.3 & 23.4 & 31.2 \\
\hline & Percentage \% & 1.52 & 0.27 & 5.7 \\
\hline \multirow[t]{4}{*}{ B-mastigophores } & Mean & 84.00 & 9.60 & $*$ \\
\hline & \pm s.d.(n) & $9.79(10)$ & $19.5(5)$ & * \\
\hline & Size $\mu \mathrm{m}$ & 19.5 & 19.5 & $*$ \\
\hline & Percentage \% & 1.28 & 0.15 & $*$ \\
\hline \multirow[t]{4}{*}{ Holotrich } & Mean & 1636.0 & $*$ & 3620.4 \\
\hline & \pm s.d.(n) & $102.9(9)$ & $*$ & $775(5)$ \\
\hline & Size $\mu \mathrm{m}$ & 31 & $*$ & 31.2 \\
\hline & Percentage \% & 24.86 & $*$ & 55.0 \\
\hline
\end{tabular}

* Not observed

Table 2

The mean skeletal and tissue characteristics of $S$. hystrix and $X$. umbellata at the study site

Principales características esqueléticas y del tejido de $S$. hystrix y $X$. umbellata en el sitio de estudio

\begin{tabular}{|c|c|c|}
\hline Characteristics & S. hystrix & X. umbellata \\
\hline \multicolumn{3}{|l|}{ Skeleton } \\
\hline Skeletal density g-cm ${ }^{-3}$ & $2.78 \pm 0.006(10)$ & $*$ \\
\hline \multicolumn{3}{|l|}{ Biomass } \\
\hline \multicolumn{3}{|l|}{ Colony } \\
\hline mg.d.t.g ${ }^{-1}$ skel. & $12.50 \pm 1.10(10)$ & \\
\hline mg.d.t.g ${ }^{-1}$ wet weight & - & $7.78 \pm 0.55(10)$ \\
\hline $\mathrm{cm}^{2} \mathrm{~g}^{-1}$ skeleton & $0.06 \pm 0.39(10)$ & $*$ \\
\hline mg.d.t. $\mathrm{cm}^{-2}$ & $0.81 \pm 0.58(10)$ & $*$ \\
\hline $\mathrm{N}^{\circ}$ polyps $\mathrm{cm}^{-2}$ & $34.38 \pm 0.00(10)$ & $*$ \\
\hline \multicolumn{3}{|l|}{ Zooxanthellae } \\
\hline $\mathrm{N}^{\circ} 10^{5} \mathrm{mg}^{-1}$ d.t. & $6.02 \pm 1.42(10)$ & $1.57 \pm 0.19(10)$ \\
\hline
\end{tabular}




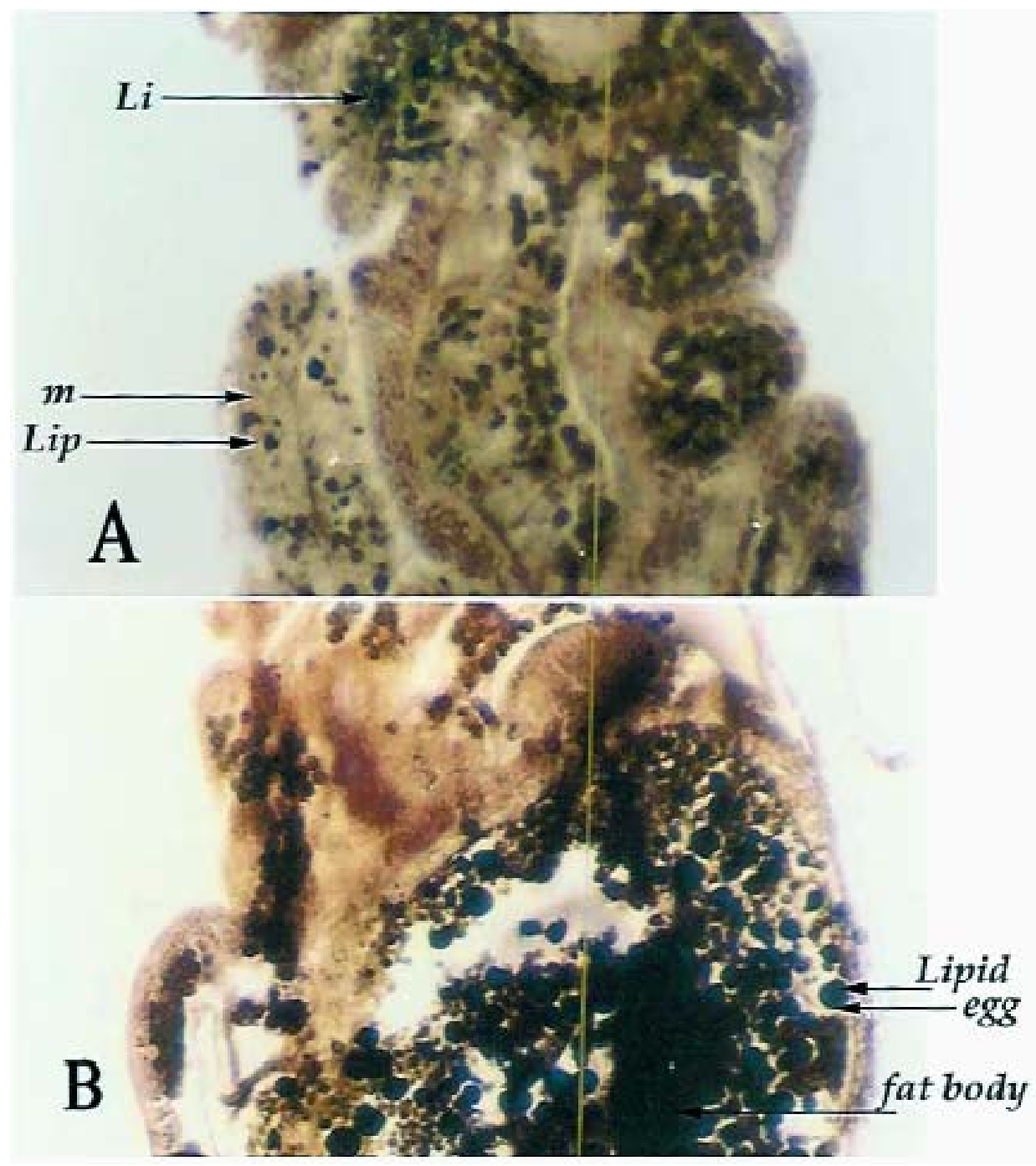

Figure 4

Longitudinal section through the mesentery of $S$. hystrix, showing black-stained lipid, lip; m, mesentery (A) and black-stained lipid, and fat body in the egg (B)

Corte longitudinal a través del mesenterio de $S$. hystrix, mostrando los lípidos teñidos de negro, lip; m, mesenterio (A) y los lípidos teñidos de negro y el cuerpo graso en el huevo (B)

In Xenia umbellata, the color of the living colonies ranged from light to dark brown. The polyp, which has eight long pinnate tentacles $(8.0 \mathrm{~mm})$, was $2.6 \mathrm{~cm}$ long and $16 \mathrm{~mm}$ in diameter. The polyp was found to be completely devoid of cnidae. The epidermis of the polyp wall was comprised of columnar epithelial cells, along with bean shaped mucous-gland cells $23 \mu \mathrm{m}$ long (Fig. 5B, C). The number of mucous-glands was high in the lower part of the polyp and did not stain blue with Alcian Blue at $\mathrm{pH}$ 1.0. The mucous-glands found in mesoglea of mesentery were oval in shape $(15 \mu \mathrm{m}$ long), and stained reddish with Alcian Blue at $\mathrm{pH} 1.0$ (Fig. 5A). Cross sections through the coelenteron of $X$. umbellata indicated that it was filled with mucus and unidentifiable small food particles and a small crustacean (Fig. 6A, B). The small food particles contained lipids that were stained black in osmiumtetroxide (Fig. 7B). 


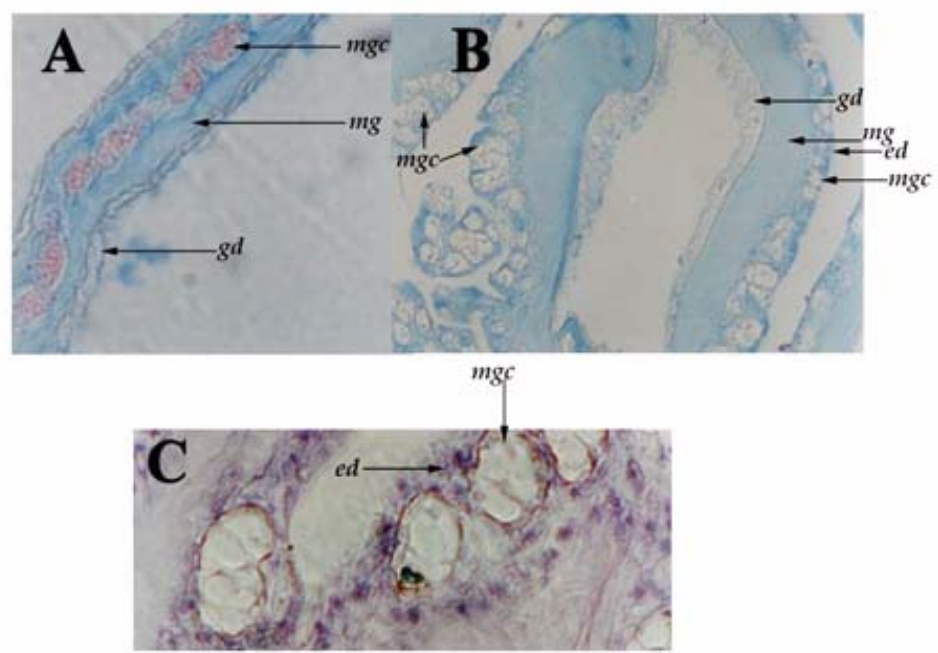

Figure 5

Longitudinal section through the lower part of $X$. umbellata polyp, showing the shape and the distribution of mucus-gland cells, when stained with Alcian Blue at pH 1.0. mgc, mucus-gland cell; gd, gastrodemis; mg, mesogloea; ed, epidermis

Corte longitudinal a través de la parte más baja del pólipo de $X$. umbellata, mostrando la forma y la distribución de las células glandulares mucosas teñidas con azul Alcian a pH 1,0. mgc, células glandulares mucosas; gd, gastrodemis; mg, mesoglea; ed, epidermis

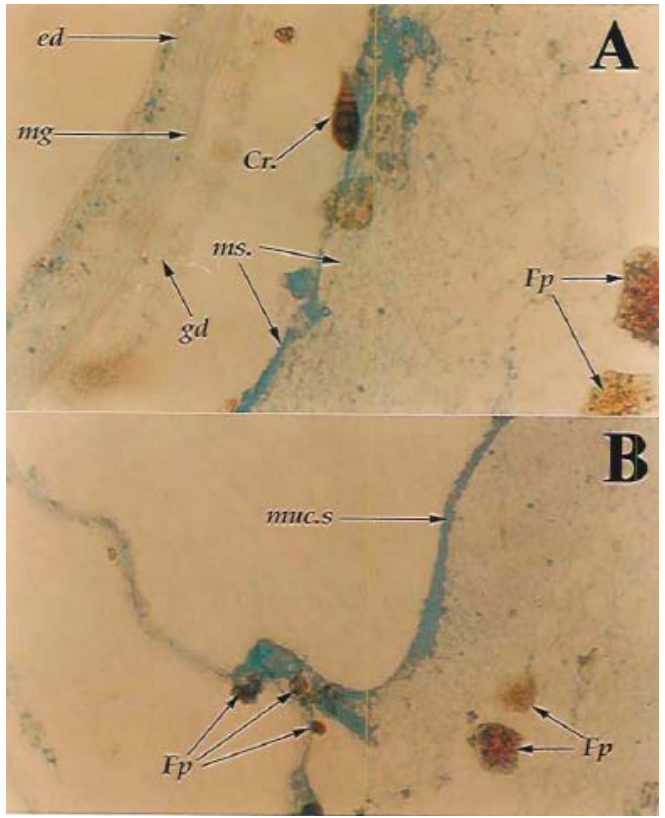

Figure 6

Cross sections (A, B) through the coelenteron of $X$. umbellata polyp, showing mucus sheet (mucus with food particles (Fp)), crustacean (Cr.), mucus sheet (ms., muc.s), epidermis (ed.), mesogloea (mg.), gastrodermis (gd.) and mucus-gland cell (mgc.)

Cortes transversales (A, B) a través del celenteron del pólipo de $X$. umbellata, mostrando una capa de mucus (mucus con partículas de alimento (Fp)) y crustáceo (Cr.), capa de mucus (ms., muc.s), epidermis (ed.), mesoglea (mg.), gastrodermis (gd.) y célula de glándula mucosa (mgc) 
The distribution of the zooxanthellae was not uniform throughout the polyp. They tended to be concentrated in the gastrodermal layer of the pinnate tentacles (Fig. 7A), whilst in the gastrodermal layer of the polyp wall, they were scarce. Their average number was $1.57 * 10^{-5} \mathrm{mg}^{-1}$ d.t. with a mean diameter of $7 \mu \mathrm{m}$ (Table 2). Lipid was again concentrated in the gastrodermal layer of the pinnate tentacles only (Fig. 7A).

\section{Tissue lipids}

The total lipid content of $S$. hystrix and $X$. umbellata was found to be and $3.37 \mathrm{mg} \mathrm{g}^{-1}$ and $6.23 \mathrm{mg} \mathrm{g}^{-1}$ respectively of dry weight of coral (Table 3 ).

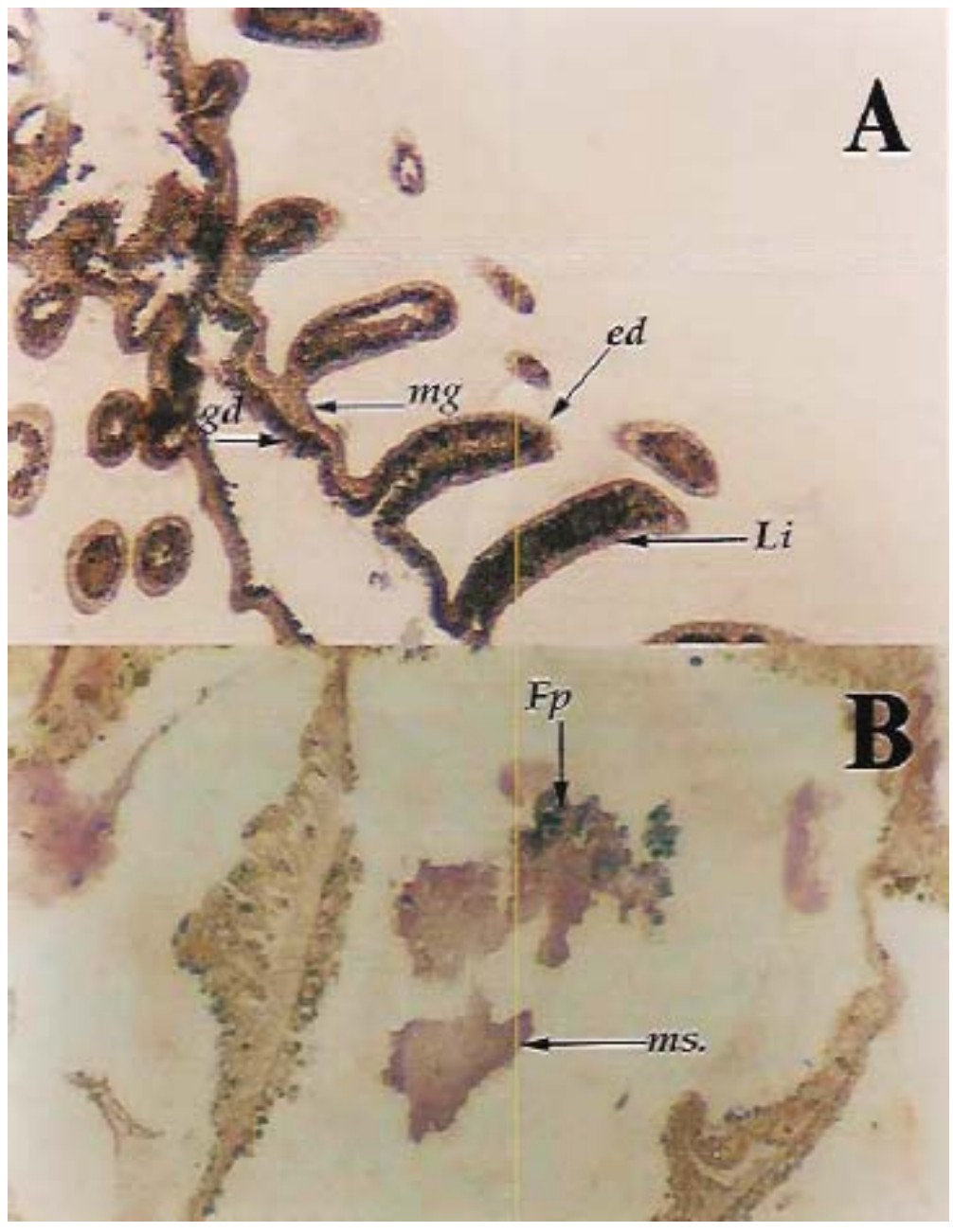

Figure 7

A. Longitudinal section through the pinnate tentacles of $X$. umbellata, showing black-stained lipid and black stained zooxanthellae when post-fixed in Potassium dichromate tetroxide solution. B. Cross section through the gastrovascular cavity of $X$. umbellata, showing food particle (Fp) stained black in the mucus sheet (ms.)

A. Corte longitudinal a través de los tentáculos pinados de $X$. umbellata, mostrando lípidos y zooxantelas teñidos de negro cuando son post-fijados en una solución de tetróxido dicromato de potasio. B. Corte transversal a través de la cavidad gastrovascular of $X$. umbellata, mostrando partículas de alimento (Fp) teñidas de negro en la capa mucosa (ms.) 
In S. hystrix, the unsaturated fatty acids were found to be $13.7 \%$ of the total. The major saturated fatty acids were palmitic acid 16:0, stearic acid 18:0, making a sum of $86.2 \%$ of the total fatty acids (Table 4). Among the methyl esters it was found that the major fatty acids in $X$. umbellata were palmitoleic acid $16: 1$; oleic acid 18:1 and arachidonic acid 20:4. The unsaturated fatty acids constituted $77.9 \%$ of the total fatty acids. The presence of 14:3 is unusual and has not been detected in other marine organisms like corals or sponges so its presence can be considered with some doubts. It was also surprising that the carbon chain was up to 20 carbon atoms, $\mathrm{C}_{20}$ or $\mathrm{C}_{22}$ were found to be absent or may be they were below detectable limits as these have been reported in other corals (Zhukova \& Titlyanov 2003).

Table 3

A comparative study of chemical components of $S$. hystrix and $X$. umbellata at the study site (mean \pm S.D., $\mathbf{n}=3$ )

Estudio comparado de los componentes químicos de $S$. hystrix y $X$. umbellata en el sitio de estudio (media \pm D.E., $\mathrm{n}=3$ )

\begin{tabular}{|c|c|c|}
\hline Components & S. hystrix & X. umbellata \\
\hline Dry matter & $91.36 \% \pm 1.510$ & $18.56 \% \pm 2.41$ \\
\hline Ash content & $53.79 \%+0.870$ & $1.79 \%+0.53$ \\
\hline Organic matter & $46.21 \% \pm 0.850$ & $98.21 \%+1.53$ \\
\hline Chlorophyll "a" $\mu g-g^{-1}$ & $5.36 \pm 0.17$ & $4.72 \pm 0.17$ \\
\hline Chlorophyll "b" $\mu g-g^{-1}$ & $4.65 \pm 0.05$ & $8.33 \pm 0.36$ \\
\hline Carbohydrates (water soluble) $\mu \mathrm{g}-\mathrm{g}^{-1}$ & $43 \pm 1.41$ & $176.0 \pm 37.01$ \\
\hline Lipids $\mu g-g^{-1}$ & $3.37+0.21$ & $6.23+0.24$ \\
\hline Protein $\mu g-g^{-1}$ & $55.52+3.31$ & $141.37 \pm 6.45$ \\
\hline Cholesterol $\mu g_{-g}-1$ & $1.24 \pm 0.15$ & $0.366 \pm 0.11$ \\
\hline
\end{tabular}

Table 4

A comparative study of fatty acid esters of $S$. hystrix and $X$. umbellata (determined by GC-MS)

Estudio comparado de los ésteres de ácidos grasos de S. hystrix y X. umbellata (determinado por GC-MS)

\begin{tabular}{lcccr}
\hline \multicolumn{1}{c}{ Esters fatty acids } & $\begin{array}{c}\text { Molecular } \\
\text { weight }\end{array}$ & $\begin{array}{c}\text { Carbon } \\
\text { chain }\end{array}$ & S. hystrix \% & X. umbellata \% \\
\hline Tetradecatrienoic acid $\mathrm{C}_{13} \mathrm{H}_{21} \mathrm{COOCH}_{3}$ & 236 & $14: 3$ & 1.24 & 4.40 \\
Tetradecanoic acid $\mathrm{C}_{13} \mathrm{H}_{27} \mathrm{COOCH}_{3}$ & 242 & $14: 0$ & 7.00 & 0.88 \\
Pentadecanoic acid $\mathrm{C}_{14} \mathrm{H}_{29} \mathrm{COOCH}_{3}$ & 256 & $15: 0$ & -- & 0.94 \\
Palmitoleic acid $\mathrm{C}_{15} \mathrm{H}_{29} \mathrm{COOCH}_{3}$ & 268 & $16: 1$ & 5.32 & 23.55 \\
Palmitic acid $\mathrm{C}_{15} \mathrm{H}_{31} \mathrm{COOCH}_{3}$ & 270 & $16: 0$ & 55.56 & 10.23 \\
Heptadecanoic acid $\mathrm{C}_{16} \mathrm{H}_{31} \mathrm{COOCH}_{3}$ & 284 & $17: 0$ & -- & 0.30 \\
Oleic acid $\mathrm{C}_{17} \mathrm{H}_{33} \mathrm{COOCH}_{3}$ & 296 & $18: 1$ & 7.33 & 33.55 \\
Stearic acid $\mathrm{C}_{17} \mathrm{H}_{35} \mathrm{COOCH}_{3}$ & 298 & $18: 0$ & 15.70 & 8.05 \\
Arachadonic acid $\mathrm{C}_{19} \mathrm{H}_{31} \mathrm{COOCH}_{3}$ & 318 & $20: 4$ & -- & 10.57 \\
Eicosenoic acid $\mathrm{C}_{19} \mathrm{H}_{37} \mathrm{COOCH}_{3}$ & 324 & $20: 1$ & -- & 5.90 \\
Eicosanoic acid $\mathrm{C}_{19} \mathrm{H}_{39} \mathrm{COOCH}_{3}$ & 326 & $20: 0$ & 7.96 & 0.33 \\
Saturated fatty acid & & & 86.22 & 20.73 \\
Unsaturated fatty acid & & & 13.77 & 77.97 \\
\hline
\end{tabular}




\section{Discussion}

The morphology of the polyps and their cells types are different in the two species. S. hystrix has small diameter polyps $(0.1 \mathrm{~mm})$ with 12 short tentacles expanding during the day and night. The colony has a large surface area to volume ratio due to the thin and sharply pointed branches. Furthermore, S. hystrix contains large numbers of zooxanthellae which were dispersed throughout the polyp wall, the coenosteum and the tentacles. These characteristics suggest that $S$. hystrix is more autotrophic (Porter 1976). On the other hand, $X$. umbellata, which has large diameter $(8.0 \mathrm{~mm})$ polyps with eight long pinnate tentacles, contains a lower number of zooxanthellae.

The pinnate tentacles often pulsate in a rhythmic opening and closing motion. This increases the water flow over the tentacles, and this together with mucus production provides an efficient mean for suspension feeding. The presence of food particles and crustaceans in the coelenteron indicates that $X$. umbellata has a more heterotrophic nutrition as in other soft corals (Lewis 1992). Symbiotic dinoflagellates from the coral release droplets in vitro; putative droplet secretion is taken as an evidence for lipid translocation from algae to the host tissue in hospite in symbiotic cnidarians (Muscatine et al. 1994). It was further studied by Patton \& Burris (1983) that when symbiotic algae were isolated from the coral Stylophora pistillata, maximum translocation occurred during the daylight i.e. from 2.00 to $7.00 \mathrm{pm}$.

The absence of specialized feeding cells in S. hystrix was shown by the histological data. Notably there are a relatively small number of mucus gland cells, a low percentage of venomous P-mastigophore (1.52-5.7\%) and B-mastigophore nematocysts (1.2-0.0\%). Conversely there is a high percentage of holotrichs nematocysts (24.86-55.0\%) in the tentacles and mesenterial filaments. P-mastigophore and B-mastigophore are used in defense and prey capture, whilst holotrichs are thought to participate in aggressive interactions (Mariscal 1974). It seems very likely therefore that this species uses these nematocysts for defense and aggression, but not for feeding. In $X$. umbellata, cnidae are absent from the polyp, their place being taken by the large number of enlarged mucous glands found in the outer layer of the coenosac, the lower part of the polyp and the mesenterial filaments. Mucus has been reported to function in food capture in corals (Al-Sofyani 1991). The mucous-gland cells of the two species reacted the same way to the Alcian Blue stain. This stain reacts with mucopolysaccharides to yield a blue colour, whilst neutral mucopolysaccharides are stained a reddish colour (Durry \& Wellington 1980).

The distribution of lipid in the gastrodermal cells, particularly those in the lower part of S. hystrix polyp, is very similar to that described for Hawaiian and Arabia Gulf corals (Stimson 1990). In the X. umbellata polyp lipid was distributed in the gastrodermal cells of the pinnate tentacles only. It appears that most of the photosynthetically-fixed carbon in the gastrodermal cells of the pinnate tentacles is used as an immediate energy supply for their metabolically high activity in feeding. It has been mentioned by other workers (Muscatine 1973 and Davies 1984) that the photosynthetic products, as a result of autotrophism, are gradually passed on to the host cells (coral) and used as a part of their nutrition. Corals tend to maintain a balance between heterotrophy and autotrophy.

Meyer (1979) had studied 45 samples of coral species and analyzed their fatty acid composition; he concluded that the corals that rely predominantly on symbiotic algae produce more saturated fatty acids. The differences in mode of feeding between the two species are further strengthened by differences in the fatty acids in the tissues. It has been postulated that unsaturated fatty acids may be derived from dietary zooplankton, fish feces, small food particles, etc., and the saturated fatty acids from zooxanthellae (Patton et al. 1977). In our study it was observed that in S. hystrix the two major fatty acids were the saturated fatty acids, palmitic and stearic acids (71.2\%). The predominance of unsaturated fatty acids in $X$. umbellata (77.7\%) along with the lipid droplet study points towards the dominance of heterotrophic feeding.

\section{Literature cited}

Al-Moghrabi S, S Allemand, JM Couret \& J Jaubert. 1995. Fatty acids of scleractinian corals Galaxea fascicularis: effect of light and feeding. Journal of Comparative Physiology, Part B, 165(3): 183-192.

Al-Sofyani AA. 1991. Physiology and ecology of Stylophora pistillata and Echinopora gemmacea from the Red Sea. Ph.D. Thesis University of Glasgow, Glasgow, 167 pp.

Clayton WS \& HR Lasker. 1982. Effect of light and darkness treatments on feeding by the reef coral. Pocillopora damicornis (Linnaeus). Journal of Experimental Marine Biology and Ecology 63(3): 269-279. 
Davies PS. 1984. The role of zooxanthellae in the nutritional energy requirements of Pocillopora eydoxi. Coral Reefs 2: 181-186.

Davies PS. 1989. Short-term growth measurements of coral using an accurate buoyant weighing technique. Marine Biology 101: 389-395.

Davies PS. 1991. Effects of daylight variations on the energy budget of shallow water corals. Marine Biology 108: 137144.

Davy SK \& CB Cook. 2001. The influence of host release factor on carbon released by zooxanthellae isolated from fed and starved Aiptasia pallida. Comparative Biochemistry and Physiology 129(3): 487-494.

Ditlev H. 1980. Reef building corals of Indo-Pacific, 83 pp. W. Backhys Publishers, Rotterdam.

Durry R \& E Wellington. 1980. Carlton's Histological Techniques, 157 pp. Oxford University Press, Oxford.

Folch J, M Lees \& GH Sloan-Stanely. 1957. A simple method for the isolation and purification of total lipids from animal tissues, Journal of Biological Chemistry 226: 497-509.

Goldberg GW. 2002. Feeding behaviour, epidermal structure and mucus cytochemistry of the scleractinian Mycetophyllia reesi, a coral without tentacles. Tissue Cell 34(4): 232-245.

Harland AD, Navaro JC, Davies PS \& LP Fixter. 1993. Lipids of some Caribbean and Red Sea corals. Marine Biology 117: 113-117.

Kellogg RB \& JS Patton. 1983. Lipid droplets, medium of energy exchange in the symbiotic anemone Condylactis gigantea: A model coral polyp. Marine Biology 75: 137-149.

Levinton JS. 1982. Limiting factors, morphology and nutrition of corals. Marine Ecology 20: 394-418.

Lewis JB. 1992. Heterotrophy in corals, Zooplankton predation by the hydrocoral Millepora complanata. Marine Ecology Progress Series 90: 251-256.

Lichtenthaler R, L Packer \& R Douse. 1987. Chlorophylls and Carotenoids: Pigments of Photosynthetic Biomembranes. Methods in Enzymology 148: 350-382.

Mariscal RN. 1974. Nematocysts. In: Muscatine L \& HM Lenhoff (eds). Coelenterate Biology: Reviews and New Perspectives, pp. 129-166. Academic Press, New York.

Meyers PA. 1979. Polyunsaturated fatty acids in corals, indicator of nutritional sources. Marine Biology Letters 1: 69-75.
Muscatine L. 1973. Nutrition of corals. In: Jones OA \& R Endean (eds), The Geology and Biology of Coral Reefs. 2: 77-115. Academic Press, New York.

Muscatine L, RD Gates \& I Lafontaine. 1994. Do symbiotic dinoflagellates secrete lipid droplets? Limnology and Oceanography 39(4): 925-929.

Oku H. 2003. Lipid biosynthesis from $C^{14}$ glucose in the coral Montipora digitata. Fisheries Science 68(3): 625-637.

Papina M, T Mezaine \& $\mathbf{R}$ vanWoesik. 2005. Symbiotic zooxanthellae provide the host coral Montipora digitata with polyunsaturated fatty acids. Comparative Biochemistry and Physiology, Part B, 135(3): 533-537.

Patton JS, S Abraham \& AA Benson. 1977. Lipogenesis in the intact coral Pocillopora capitata and its isolated zooxanthellae: Evidence for a light driven carbon cycle between symbiont and host. Marine Biology 44: 235-247.

Patton JS \& JE Burris. 1983. Lipid synthesis and extrusion by freshly isolated zooxanthellae (symbiotic algae). Marine Biology 75: 131-136.

Porter JW. 1976. Autotrophy, heterotrophy and resource partitioning in Caribbean reef building corals. Limnology and Oceanography 18: 380-385.

Reynaud S, C Ferrier-Pagès, R Sambrotto, A JuilletLeclerc, J Jaubert \& J-P Gattuso. 2002. Effect of feeding on the carbon and oxygen isotopic composition in the tissues and skeleton of the zooxanthellate coral Stylophora pistallata. Marine Ecology Progress Series 238: 81-89.

Stimson JS. 1990. Stimulation of fat-body production in the polyps of the coral Pocillopora damicornis by the presence of mutualistic crabs of the genus Trapezia. Marine Biology 106: 211-218.

Szmant-Froelich A \& MEQ Pilson. 1980. The effect of feeding frequency and symbiosis with zooxanthellae on biochemicals composition of Astrangia danae Milne Edwards \& Haime, 1849. Journal of Experimental Marine Biology and Ecology 48(1): 85-87.

Thorington GU \& DA Hessinger. 1990. Control of cnida discharge: III. Spirocysts are regulated by three classes of chemoreceptors. The Biological Bulletin 178: 74-83.

Wellington GM. 1982. An experimental analysis of the effects of light and zooplankton on coral zonation. Oecologia 52: 311-320.

Zhukova NV \& EA Titlyanov. 2003. Fatty acid variations in symbiotic dinoflagellates from Okinawa corals. Phytochemistry 62(2): 191-195. 